\title{
COMPARATIVE STUDY OF INCIDENCE OF POST DURAL PUNCTURE HEADACHE WITH 25 GAUGE QUINCKE AND 25 GAUGE WHITACRE NEEDLES IN OBSTETRIC PATIENTS
}

\author{
Shaikh Tahoor ${ }^{1}$, Rammoorthi Rao ${ }^{2}$
}

${ }_{1}^{1}$ Third Year Postgraduate Student, Department of Anaesthesiology, Kasturba Medical College, Mangalore. ${ }^{2}$ Associate Professor, Department of Anaesthesiology, Kasturba Medical College, Mangalore.

\begin{tabular}{l}
\hline ABSTRACT \\
BACKGROUND \\
Post dural puncture headache (PDPH) has been the most common complications of spinal anaesthesia especially in obstetric \\
patients. After needle gauge, tip design is an important factor determining rate of incidence of post dural puncture headache.
\end{tabular}

Aim- Comparison of incidence of post dural puncture headache with 25 gauge quincke and 25 gauge whitacre needle in obstetric patients

\section{MATERIALS AND METHODS}

Total of 80 patients posted for caesarean section were divided in two groups each comprising 40. Group A-spinal anaesthesia with 25 gauge quincke needle, Group B-spinal anaesthesia with 25 gauge whitacre needle. Patients were observed for level of sensory blockade, bromage score, incidence of hypotension, shivering, nausea, vomiting and development of PDPH post spinal anaesthesia

\section{RESULTS}

Incidence of PDPH found was 5\% in group of quincke needle and was absent in group of whitacre needle. Other parameters were similar and comparable in both groups but bromage score was higher in quincke group than whitacre.

\section{CONCLUSION}

No significant difference was found in incidence of PDPH in both needle groups in obstetric patients. Quincke needle group was found to be associated with higher bromage score than whitacre needle group.

\section{KEYWORDS}

25G Quincke Needle, 25G Whitacre Needle, Post Dural Puncture Headache.

HOW TO CITE THIS ARTICLE: Tahoor S, Rao R. Comparative study of incidence of post dural puncture headache with 25 gauge quincke and 25 gauge whitacre needles in obstetric patients. J. Evolution Med. Dent. Sci. 2017;6(10):757-760, DOI: $10.14260 /$ Jemds/2017/164

\section{BACKGROUND}

Post dural puncture headache has been a troublesome complication of spinal anaesthesia since 1898 when Bier and Hildebrnadt produced $100 \%$ incidence of this complication while performing spinal anaesthesia. ${ }^{1,2}$ Two aspects of its pathophysiology is evident excessive loss of CSF through dural puncture in epidural space and the resultant painful vasodilatation of intracranial vessels due to downward traction on them.2,3,4

Various studies have shown post dural puncture headache occurs usually 12-48 hours after dural puncture with headache in bilateral frontal and occipital region. ${ }^{5}$ Factors associated with post dural puncture headache are pregnancy, youth and female sex and intraoperative variables like patient position, bevel orientation, type and size of needle, type and baricity of anaesthetic agent, addition of opioid and administration of intraoperative sedation.2,6,7

Financial or Other, Competing Interest: None.

Submission 25-12-2016, Peer Review 09-01-2017,

Acceptance 24-01-2017, Published 02-02-2017.

Corresponding Author:

Dr. Shaikh Tahoor,

Flat No. T1, 3 ${ }^{\text {rd }}$ Floor, Le Royale Apartment,

Above Swarnadeep Agency, Near Kidzee School,

Bishop Victor/New Attavar Road,

Attavar, Mangalore-575001, Karnataka.

E-mail: tahurshaikh@gmail.com

DOI: $10.14260 /$ jemds $/ 2017 / 164$

\section{(c) $(1)$}

After tip design, needle gauge is the second most important factor determining rate of PDPH. Early studies have reported incidence of PDPH with Quincke needle to range from $1.5-3.7 \%$ and as high as $10.4 \%$ and with noncutting needle to be $0.02 \% .8,9$

To minimize these problems, conical tipped needles with pencil point have become popular like sprotte, green and whitacre needles which are designed basically to spread dural fibres at point of puncture rather than cutting it caused by quincke needles. The PDPH incidence was found less since needles with pencil point separates dural fibres rather than cutting it during dural puncture. ${ }^{10}$

Hypotension and high incidence of PDPH were two main reasons for decline in popularity of spinal anaesthesia in young, otherwise healthy pregnant population. In 1951, Whitacre based on observation of Green study, developed special fibre splitting needles with pencil point which ultimately led to significant reduction in post dural puncture headache incidence. With the development of newer needles, bevel design and methods by which incidence of PDPH and hypotension can be minimized, spinal anaesthesia has made reappearance in obstetric anaesthesia. ${ }^{11,12}$

\section{MATERIALS AND METHODS}

The study design was an observational comparative study which was conducted at an obstetrics and gynaecology hospital Mangalore.

Sample size of 80 to be divided in two groups of 40 was calculated with $95 \%$ confidence level and $90 \%$ power. To 
analyse the data Chi Square test statistical package SPSS 17 was used to compare between groups. When $\mathrm{P}<0.05$ was found it was considered statistically significant and when $p>0.05$ was found it was considered statistically nonsignificant. When $\mathrm{P}<0.01$ was found it was considered highly significant. The study was carried out in 80 female obstetric patients in the age group of 18 to 46 years undergoing elective or emergency lower segment caesarean section and belonging to ASA (American Society of Anaesthesiologist) grade 2. Group A-40 obstetric patients were given spinal anaesthesia with quincke needle of $25 \mathrm{G}$, Group B- 40 obstetric patients were given spinal anaesthesia with whitacre needle of 25G.

Exclusion criteria was when patient did not give consent, any incidence of local sepsis, patients with spinal deformity/surgery, deranged coagulation profile, space occupying lesions of brain, pregnancy induced hypertension, foetal distress and multiple pregnancy. A pre anaesthetic check-up was done for all patients.

All patients were given aspiration prophylaxis on the previous night and also on the day of surgery with injection ranitidine $50 \mathrm{mg}$ and injection metoclopramide $10 \mathrm{mg}$. For elective surgery, patient were kept fasting for 6 hours prior to spinal anaesthesia. On arrival in operating room, iv cannulation was done on non-dominant hand with $18 \mathrm{~g}$ cannula and preloading with crystalloids was done at $15 \mathrm{ml} / \mathrm{kg}$. In operating room all patient were monitored with a pulse oximeter, an electrocardiogram and non-invasive $\mathrm{BP}$ throughout the procedure and base line vitals noted.

Under all aseptic precautions patient back was cleaned with beta iodine and spirit and draped. After preparing back, local block by $2 \mathrm{ml}$ of $2 \%$ lignocaine was infiltrated in L3-L4 or L4-L5 space. Spinal needle was introduced with ejection orifice parallel to dural fibres. Upon entering subarachnoid space evidenced by free flowing CSF, needle was rotated so that ejection orifice was directed cephalad. CSF was again aspirated to confirm placement and $2 \mathrm{ml}(10 \mathrm{mg})$ of $0.5 \%$ (Hyperbaric)bupivacaine was been injected over 20 seconds. After block, patients were kept in supine position and were also given 15 to 20 degree left displacement of uterus until birth by keeping a wedge under right buttock.

Sensory level of block was assessed by temperature (Cold water swab) and by pin prick at mid clavicular line.

\section{Motor Block was assessed by Bromage Score-}

1. Full range flexion of knees and feet.

2. Were just able to move knees.

3. Were able to move feet only.

4. Completely unable to move feet or knees.

Final score of motor blockade and sensory blockade level was taken at the end of 30 minutes. No sedation was given intraoperatively. Oxygen 5 litres/ minute by was given by Hudson mask until delivery of baby. Intraoperatively fluid status was maintained according to blood pressure. Heart rate, non-invasive arterial blood pressure and Spo2 (Blood oxygen saturation) was evaluated every 2 minutes for initial first 20 minutes and then every 5 minutes each until completion of procedure. All episodes of hypotension, shivering, nausea and vomiting, somnolescence, decrease in minute ventilation and pain if present were recorded. Patients were observed for post-operative day 1, 2 and 3 for development of post dural puncture headache.

\section{PDPH was defined when it fulfilled following Two} Criteria

1. Location of headache in frontal and occipital areas of head.

2. Increase in symptoms while standing or sitting.

\section{RESULTS}

Statistical analysis was performed using SPSS package 17 software. There was no statistical significant difference among variables like age, weight, height, incidence of hypotension, shivering, nausea, vomiting and sensory block achieved after block in two needle groups. Chi square test was used to analyse the study and $\mathrm{p}$ value $>0.05$ was considered not significant.

A higher degree of bromage score for motor blockade was achieved in quincke needle group than in whitacre needle group. Calculated by chi square test, $\mathrm{p}$ value was found to be $0.045(<0.05)$ hence statistically significant.

The difference in required number of attempts for block was statistically not significant in two needle groups. Post dural puncture headache incidence was $5 \%$ in quincke needle group and was absent in whitacre needle group. Calculated by Fishers exact test $p$ value was $0.247(>0.05)$ hence statistically not significant.

\begin{tabular}{|c|c|c|c|c|}
\hline Group & $\mathbf{N}$ & Mean & $\begin{array}{c}\text { Standard. } \\
\text { Deviation }\end{array}$ & \\
\hline Group A & 40 & 27.85 & 4.004 & $\mathrm{t}=1.905, \mathrm{p}=0.060$, \\
Group B & 40 & 26.25 & 3.492 & NS \\
\hline \multicolumn{5}{|c|}{ Table 1. Age } \\
\hline
\end{tabular}

\begin{tabular}{|c|c|c|c|c|c|}
\hline & Group & $\mathbf{N}$ & Means & $\begin{array}{c}\text { Std. } \\
\text { Deviation }\end{array}$ & \\
\hline \multirow{2}{*}{ Weight } & Group A & 40 & 55.88 & 7.750 & $\mathrm{t}=.063$, \\
\cline { 2 - 5 } & Group B & 40 & 55.75 & 9.836 & $\mathrm{p}=0.950, \mathrm{NS}$ \\
\hline \multirow{2}{*}{ Height } & Group A & 40 & 158.53 & 6.737 & $\mathrm{t}=.991$, \\
\cline { 2 - 5 } & Group B & 40 & 157.05 & 6.575 & $\mathrm{p}=0.325, \mathrm{NS}$ \\
\hline
\end{tabular}

Table 2. Weight and height

\begin{tabular}{|c|c|c|c|c|}
\hline & & \multicolumn{2}{|c|}{ Group } & \multirow{2}{*}{ Total } \\
\hline & & Group A & Group B & \\
\hline \multirow{6}{*}{$\begin{array}{l}\text { No. of Attempts } \\
\text { for Block }\end{array}$} & 1. Count & 30 & 26 & 56 \\
\hline & \% Within Group & $75.0 \%$ & $65.0 \%$ & $70.0 \%$ \\
\hline & 2. Count & 10 & 13 & 23 \\
\hline & \% Within Group & $25.0 \%$ & $32.5 \%$ & $28.8 \%$ \\
\hline & 3. Count & 0 & 1 & 1 \\
\hline & \% Within Group & $.0 \%$ & $2.5 \%$ & $1.3 \%$ \\
\hline \multirow[t]{2}{*}{ Total } & Count & 40 & 40 & 80 \\
\hline & \% Within Count & $100.0 \%$ & 100.0 & 100.0 \\
\hline
\end{tabular}

\begin{tabular}{|c|c|c|c|c|}
\hline & & \multicolumn{2}{|c|}{ Group } & \multirow{2}{*}{ Total } \\
\hline & & Group A & Group B & \\
\hline \multirow{4}{*}{$\begin{array}{c}\text { Sensory } \\
\text { Block }\end{array}$} & T4 Count & 8 & 12 & 20 \\
\hline & $\begin{array}{l}\text { \% Within } \\
\text { Group }\end{array}$ & $20.0 \%$ & $30.0 \%$ & $25.0 \%$ \\
\hline & T6 Count & 32 & 28 & 60 \\
\hline & $\begin{array}{l}\text { \% Within } \\
\text { Group }\end{array}$ & $80.0 \%$ & $70.0 \%$ & $75.0 \%$ \\
\hline \multirow[t]{2}{*}{ Total } & Count & 40 & 40 & 80 \\
\hline & $\begin{array}{l}\text { \% Within } \\
\text { Group }\end{array}$ & $100.0 \%$ & $100.0 \%$ & $100.0 \%$ \\
\hline
\end{tabular}




\begin{tabular}{|c|c|c|c|c|}
\hline & & \multicolumn{2}{|c|}{ Group } & \multirow{2}{*}{ Total } \\
\hline & & Group A & Group B & \\
\hline $\begin{array}{c}\text { Bromage } \\
\text { Score }\end{array}$ & 3. Count & 7 & 15 & 22 \\
\hline & $\begin{array}{c}\text { \% Within } \\
\text { Group }\end{array}$ & $17.5 \%$ & $37.5 \%$ & $27.5 \%$ \\
\hline & 4. Count & 33 & 25 & 58 \\
\hline & $\begin{array}{c}\% \text { Within } \\
\text { Group }\end{array}$ & $82.5 \%$ & $62.5 \%$ & $72.5 \%$ \\
\hline Total & Count & $\mathbf{4 0}$ & $\mathbf{4 0}$ & $\mathbf{8 0}$ \\
\hline & $\begin{array}{c}\text { \% Within } \\
\text { Group }\end{array}$ & $100.0 \%$ & $100.0 \%$ & $100.0 \%$ \\
\hline \multicolumn{5}{|c|}{$\begin{array}{c}\text { Table 5. Bromage score* group } \\
\text { cross tabulation }\end{array}$} \\
\hline
\end{tabular}

\begin{tabular}{|c|c|c|c|c|}
\hline & & \multicolumn{2}{|c|}{ Group } & \multirow{2}{*}{ Total } \\
\hline & & Group A & Group B & \\
\hline $\begin{array}{c}\text { Incidence of } \\
\text { Hypotensior }\end{array}$ & - Count & 29 & 22 & 51 \\
\hline & $\begin{array}{c}\% \text { Within } \\
\text { Group }\end{array}$ & $72.5 \%$ & $55.0 \%$ & $63.8 \%$ \\
\hline & + Count & 11 & 18 & 29 \\
\hline & $\begin{array}{c}\text { \% Within } \\
\text { Group }\end{array}$ & $27.5 \%$ & $45.0 \%$ & $36.3 \%$ \\
\hline Total & Count & $\mathbf{4 0}$ & $\mathbf{4 0}$ & $\mathbf{8 0}$ \\
\hline & $\begin{array}{c}\text { \% Within } \\
\text { Group }\end{array}$ & $100.0 \%$ & $100.0 \%$ & $100.0 \%$ \\
\hline \multicolumn{5}{|c|}{ \%able 6. Incidence of hypertension } \\
*group cross tabulation
\end{tabular}

\begin{tabular}{|c|c|c|c|c|}
\hline & & \multicolumn{2}{|c|}{ Group } & \multirow{2}{*}{ Total } \\
\hline & & Group A & Group B & \\
\hline \multirow{3}{*}{$\begin{array}{c}\text { Incidence } \\
\text { of Nausea }\end{array}$} & $\begin{array}{c}\text { \% Within } \\
\text { Group }\end{array}$ & $90.0 \%$ & $95.0 \%$ & $92.5 \%$ \\
\cline { 2 - 4 } & + Count & 4 & 2 & 6 \\
\cline { 2 - 4 } & $\begin{array}{c}\text { \% Within } \\
\text { Group }\end{array}$ & $10.0 \%$ & $5.0 \%$ & $7.5 \%$ \\
\hline Total & Count & $\mathbf{4 0}$ & $\mathbf{4 0}$ & $\mathbf{8 0}$ \\
\hline \multirow{4}{*}{$\begin{array}{c}\text { \% Within } \\
\text { Group }\end{array}$} & $100.0 \%$ & $100.0 \%$ & $100.0 \%$ \\
\hline \multicolumn{4}{|c|}{$\begin{array}{c}\text { Table 7. Incidence of nausea } \\
\text { *group cross tabulation }\end{array}$} \\
\hline
\end{tabular}

\begin{tabular}{|c|c|c|c|c|}
\hline & & \multicolumn{2}{|c|}{ Group } & \multirow{2}{*}{ Total } \\
\hline & & Group A & Group B & \\
\hline \multirow{4}{*}{$\begin{array}{l}\text { Incidence of } \\
\text { Shivering }\end{array}$} & - Count & 33 & 36 & 39 \\
\hline & $\begin{array}{l}\text { \% Within } \\
\text { Group }\end{array}$ & $82.5 \%$ & $90.0 \%$ & $86.3 \%$ \\
\hline & + Count & 7 & 4 & 11 \\
\hline & $\begin{array}{l}\text { \% Within } \\
\text { Group }\end{array}$ & $17.5 \%$ & $10.0 \%$ & $13.8 \%$ \\
\hline \multirow[t]{2}{*}{ Total } & Count & 40 & 40 & 80 \\
\hline & $\begin{array}{l}\text { \% Within } \\
\text { Group }\end{array}$ & $100.0 \%$ & $100.0 \%$ & $100.0 \%$ \\
\hline \multicolumn{5}{|c|}{$\begin{array}{l}\text { Table 8. Incidence of shivering } \\
\quad \text { *group cross tabulation }\end{array}$} \\
\hline
\end{tabular}

\begin{tabular}{|c|c|c|c|c|}
\hline & & \multicolumn{2}{|c|}{ Group } & \multirow{2}{*}{ Total } \\
\hline & & Group A & Group B & \\
\hline \multirow{4}{*}{$\begin{array}{c}\text { Incidence of } \\
\text { Post Dura } \\
\text { Puncture } \\
\text { Headache }\end{array}$} & - Count & 38 & 40 & 78 \\
\hline & $\begin{array}{l}\text { \% Within } \\
\text { Group }\end{array}$ & $95.0 \%$ & $100.0 \%$ & $97.5 \%$ \\
\hline & + Count & 2 & 0 & 2 \\
\hline & $\begin{array}{l}\text { \% Within } \\
\text { Group }\end{array}$ & $5.0 \%$ & $.0 \%$ & $2.5 \%$ \\
\hline \multirow[t]{2}{*}{ Total } & Count & 40 & 40 & 80 \\
\hline & $\begin{array}{l}\text { \% Within } \\
\text { Group }\end{array}$ & $100.0 \%$ & $100.0 \%$ & $100.0 \%$ \\
\hline \multicolumn{5}{|c|}{$\begin{array}{l}\text { Table 9. Incidence of post dural puncture } \\
\text { headache * cross tabulation }\end{array}$} \\
\hline
\end{tabular}

\begin{tabular}{|c|c|c|c|c|c|}
\hline & \multicolumn{2}{|c|}{$\begin{array}{c}\text { Chi Square } \\
\text { Test }\end{array}$} & & \multicolumn{2}{c|}{$\begin{array}{c}\text { Fishers Exact } \\
\text { Test }\end{array}$} \\
\hline & $\begin{array}{c}\text { X2= } \\
\text { Value }\end{array}$ & $\begin{array}{c}\text { Palue } \\
\text { Vals }\end{array}$ & & P= & \\
\hline $\begin{array}{c}\text { No. of Attempts } \\
\text { for Block *Group }\end{array}$ &. &. &. & .471 & NS. \\
\hline $\begin{array}{c}\text { Sensory Block } \\
{ }^{*} \text { Group }\end{array}$ & 1.067 & .302 & NS & & \\
\hline $\begin{array}{c}\text { Bromage Score } \\
{ }^{*} \text { Group }\end{array}$ & 4.013 & .045 & sig & & \\
\hline $\begin{array}{c}\text { Incidence of } \\
\text { Hypotension } \\
* \text { Group }\end{array}$ & 2.650 & .104 & NS & & \\
\hline $\begin{array}{c}\text { Incidence of } \\
\text { Nausea *Group }\end{array}$ & .180 & .671 & NS & & \\
\hline $\begin{array}{c}\text { Incidence of } \\
\text { Shivering *Group }\end{array}$ & .949 & .330 & NS & & \\
\hline $\begin{array}{c}\text { Incidence of Post } \\
\text { Dural Puncture } \\
\text { Headache *Group }\end{array}$ &. & & & .247 & NS \\
\hline \multicolumn{1}{|c|}{ Table 10.P value } & & \\
\hline
\end{tabular}

\section{DISCUSSION}

In this study no significant difference was found in mean age of patients of group A and group B with $\mathrm{p}$ value of 0.06 $(>0.05)$. This was expected as patients in both groups were young females posted for lower segment caesarean section with age ranging from 21 to 36 years. ${ }^{13}$ No significant difference in mean height and weight of patients was found in this study with a p value of $0.325(>0.05)$ for height and a $p$ value of $0.950(>0.05)$ for weight.

Height of sensory blockade achieved in both groups was upto T4 or T6. Statistically no significant difference was found in two needle groups with a p value of $0.302(>0.05)$ in respect to maximum sensory block achieved. Degree of motor blockade by bromage criteria was either 3 or 4 in both needle groups. But a higher percentage of quincke needle group had a bromage score of $4(82.5 \%)$ as compared to whitacre needle group $(62.5 \%) .{ }^{14}$ With a p value of $0.045(<0.05)$ it was found statistically significant.

Most of the blocks in both groups were performed in first attempt itself. Second attempt was required in 10 patients in quincke group and in 13 patients in whitacre group. Third attempt was required only in one patient in whitacre group. Out of two patients who developed PDPH in quincke group, one was performed in first attempt and other in two attempts. With a p value of $0.471(>0.05)$ it was statistically 
insignificant. Whitacre needle was associated with fewer cases of PDPH and was easier to accomplish block as compared to quincke needle. ${ }^{13}$

In this study it was observed that incidence of hypotension is very common following spinal anaesthesia in caesarean delivery. Its incidence was more in whitacre group (45\%) as compared to quincke group (27.5\%). But with a p value of $0.104(>0.05)$ it was statistically insignicant. Its severity and incidence depend on maximum height of blockade, aortocaval compression and total circulating blood volume. ${ }^{2,15}$ In this study it was observed that shivering was present in $17.5 \%$ cases in quincke group and in $10 \%$ cases in whitacre group. With a p value of $0.330(>0.05)$ it was statistically insignificant. Possible cause of intraoperative shivering is sympathetic nervous system blockage resulting in peripheral pooling and vasodilatation, increased in cutaneous area blood flow and increased heat loss via skin.2,16 A $10 \%$ incidence of vomiting and nausea in quincke group and $5 \%$ incidence in whitacre group was observed. In this study almost all patients who had nausea and vomiting also had hypotension. This nausea vomiting could be due to effect relating to maternal hypotension which causes decreased cerebral blood flow. ${ }^{2}$

In this study only 2 patients developed post dural puncture headache in quincke group ( $5 \%$ incidence) whereas it was absent in whitacre group. Both cases of PDPH were observed after 24 hours of spinal anaesthesia. Both cases were moderate in severity which limited activity of patients and were advised bed rest. Headache was relieved with reassurance, rest, iv fluids and regular analgesics. No epidural patch was required. Calculated $\mathrm{p}$ value was $0.247(>0.05)$ hence statistically not significant.

\section{CONCLUSION}

The study done did not show significant difference in incidence of PDPH in quincke and whitacre needle groups when used for spinal anaesthesia in caesarean sections. Attempts at spinal anaesthesia also did not show any correlation with development of PDPH although maximum only 2 attempts were required during study. Sensory block achieved in both group was similar and comparable but a higher depth of motor blockade was achieved in quincke needle group.

Incidence of hypotension was common overall in both groups inspite of preloading preoperatively. No significant difference was found in two needle types. Similarly incidence of vomiting, nausea and shivering was similar and comparable in two needle types and no significant difference was found.

\section{Acknowledgement}

I acknowledge wholehearted and full support of Kasturba Medical College, Mangalore and Manipal University, Manipal, India in conducting this study.

\section{REFERENCES}

[1] Gerancher JC, LIU SS. Complications of neuraxial anaesthesia. In: Jonathan LB, Lawrence JS. Anaesthesia and perioperative complications. $2^{\text {nd }}$ edn. Mosby 1999:50-65.

[2] Srivastava V, Jindal P, Sharma JP. Study of post dural puncture headache with $27 \mathrm{G}$ quincke \& whitacre needles in obstetrics/non obstetrics patients. Middle East J Anaesthesiol 2010;20(5):709-17.

[3] Norris MC, Leighton BL, DeSimon CA. Needle bevel direction and headache after inadvertent dural puncture. Anaesthesiology 1989;70(5):729-31.

[4] Green HM. Lumbar puncture and prevention of post dural puncture headache. JAMA 1926;15:22-5.

[5] Evans RW. Complications of lumbar puncture. Neurology 2005;55:909-14.

[6] Hapren S, Freston R. Postdural puncture headache and spinal needle design. Meta analysis anaesthesiology. American academy of neurology 1994;10:11-7.

[7] Carson D, Serpell M. Choosing the best needle for diagnostic lumbar puncture. Neurology 1996;47(1):33-7.

[8] Santanen U, Rautoma P, Luurila H, et al. Comparison of 27-gauge $(0.41-\mathrm{mm})$ whitacre and quincke spinal needles with respect to post-dural puncture headache and non-dural puncture headache. Acta Anaesthesiol Scand 2004;48(4):474-9.

[9] Carmel A, Evans RW. Addendum to assessment: prevention of post-lumbar puncture headaches. Special article neurology 2005:909-11.

[10] Campbell DC, Douglas MJ, Pavyet TJG, et al. Comparison of the 25-gauge whitacre with the 24gauge sprotte spinal needle for elective caesarean section: cost implications. Canadian Journal of Anaesthesia 1993;40:1131-35.

[11] Vandam LD. On the origins of intrathecal anaesthesia. Int anaesthesiology Clin 1989;27(1):2-7.

[12] Berges PU. Regional anaesthesia for obstetrics. Journal of clinical anaesthesiology 1969;2:141-66.

[13] de Fernández DR, Madrid TML, Torrente CP, et al. Comparison of two 27-g-calibre needles for spinal anaesthesia. Study of 1,555 patients. Rev Esp Anestesiol Reanim 2003;50(4):182-7.

[14] Tabedar S, Maharjan SK, Shrestha BR, et al. a comparison of 25 gauge quincke spinal needle with 26 gauge eldor spinal needle for elective caesarean section: insertion characteristics and complications. Kathmandu universitv medical journduraal 2003;1(4):263-6.

[15] Campbell. Comparison of 27-g whitacre with 27-g quincke needle for elective LSCS: cost implications. Can journal anaesthesiology 1993;40(12):1131-5.

[16] Crossley AWA. Peri-operative shivering. Journal of Anaesthesia 1992;47(3):193-5. 